Article

\title{
Ideal-Type Narratives for Engineering a Human Niche
}

\author{
Martin Bohle \\ European Commission, Directorate General for Research and Innovation, Rue de la Loi 200, 1049 Brussels, \\ Belgium; martin.bohle@ec.europa.eu; Tel.: +32-2-2958111 \\ Academic Editor: Jesús Martínez Frías \\ Received: 23 January 2017; Accepted: 20 March 2017; Published: 22 March 2017
}

\begin{abstract}
Humans have built an anthropocentric biogeosphere; called: 'human niche'. Global change is part of this historical process of niche construction, which implies the intersection of the biogeosphere and the sphere of human activities of social, economic, cultural, and political natures. To construct these intersections, modern-day societies deploy 'engineered systems' and build narratives to frame these activities with purpose. This essay describes: (i) perceptions of what 'engineered systems' are about, (ii) their context such as global change, human agency, and societal implications of applied geosciences, and (iii) related narratives on how to handle global change through the design of 'engineered systems'. Subsequently, regarding underpinning insights, it is shown that they: (i) are well-known, were used in the past, and now may be applied to handle global change; (ii) enshrine a distinct choice on how human activities and the biogeosphere shall intersect; and (iii) can be described by a simple ideal-type scheme, which does not require detailed scientific-technical understanding. Subsequently, it is illustrated how this ideal-type scheme leads to different narratives about what kind of 'engineered systems' are preferred. It is concluded that such ideal-type narratives for a messy world may help a lay-public to choose between options regarding how to handle global change.
\end{abstract}

Keywords: global change; narrative; biogeosphere; engineering; applied geosciences; Anthropocene

\section{Introduction}

Applied geoscience is essential for the operation of effective and efficient 'engineered systems' to produce, distribute, and consume goods and services. The design and operation of such systems imply choices, which determine their particular configuration that in turn may result in a differently engineered 'human niche'. Taking a natural-science and engineering angle of view to describe such configurations, this essay proposes generic features that can be understood without specific technical or scientific knowledge, and therefore may help non-specialists to take an informed opinion.

The notion of 'engineering' is referred to in French and German as 'genie civil' and 'Ingenieurskunst', respectively. Rather than being limited as the English 'engineering', the corresponding French or German notions connote a more substantial concept, namely the design and operation of purposely built and often larger-scale environments of artifacts like human dwellings, production systems, and consumption patterns. Lately, such already substantiated notions of 'engineering' have been widened further to concepts such as 'ecological engineering' [1].

Using the notion of 'engineering' in the wider sense of 'genie civil' and 'Ingenieurskunst', this essay discuss an ideal-type description of various conceptual schemes to engineer a human niche. This notion, 'to engineer a human niche', shall label how people configure the intersections between the biogeosphere and the 'human sphere' of arts, social interactions, and the economy. Thus, this notion has a scope that differs from the notion of 'geo-engineering'. The latter habitually connotes the 
tuning of features of the geosphere to counter global warming, The notion 'to engineer a human niche' also shall remind us of the generic purpose of 'engineered systems', namely to produce, distribute, and consume goods and services.

The approach used in this paper is inspired by Bellamy and co-workers [2], who analyse storytelling to distill insights from earth sciences [3,4]. However, rather than presenting an empirical analysis that compares various configurations of intersections between the biogeosphere and the 'human sphere', this essay presents four ideal-types using a qualitative description

- of the intervention points that are targeted by an engineered system,

- of the levels of consensus that are needed for an effective deployment of an engineered system,

- of the perceptions of what human undertakings can achieve ('human agency'),

- of the opinions about how 'nature' and 'culture' relate to each other,

- of the ways in which previous investments (economic, social, cultural) are safeguarded, and

- of the choice between well-worn and innovative technologies.

It is a particular application case to engineer at a global scale because of the intricate sets of interlocking features that interact and shape the decision making process, such as: the complexity of an Earth system consisting of a volatile global economy coupled to the biogeosphere, and the large diversity of world-views, socio-cultural features, and preferences. Narratives associated with how 'to engineer a human niche' have issues in common: (i) The earth systems dynamics are non-linear with multiple and interlocking positive and negative feedback loops $[5,6]$. Therefore, the dynamics are chaotic, difficult to forecast, and counter-intuitive. Consequently the value-driven and perception-laden conception, planning, and operation of engineered systems that determine production systems and consumption patterns are wicked problems. Thus, problem handling has to be iterative, path-dependent, and open-ended $[7,8]$. (ii) People may face choices regarding their lifestyles and an effective engineering of these systems and patterns will benefit from public consensus. Therefore publicly acceptable messages will be needed, including the insight that the alteration of Earth systems is a conscious act, which renders the actor liable [9]. (iii) A range of ethical dilemmas will arise, such as how to cope with conflicting values or an uneven distribution of hazards, how to manage benefits, challenges to individual lifestyles and basic needs, or how to assist people or states, for example, in the case of relocation out of flooded coastal zones [10,11].

This paper is constructed in four main sections. Following this introduction, the first section presents perspectives that form the methodology on how to mutually contextualize 'engineering', 'applied geosciences', 'building of a human niche', and 'narratives'. The second section outlines the different conceptual approaches (schemes) 'how to engineer' and related narratives: Initially, an illustrative description is given that then is followed by a schematic approach, i.e., ideal-types that are end-points of opposing pairs of descriptors. The third section describes the manner in which these narratives may relate to each other in a messy world. The last section summarizes the essay and outlines how a lay public may benefit from ideal-type narratives about engineering a human niche.

\section{Framing Perspectives}

This section presents perspectives how to put into a common context notions that habitually are treated apart. In this manner, this section presents the methodology that is used to conceptualize four ideal-type narratives.

\subsection{Geo-, Bio-, Noosphere, and Other Notions}

In this essay, the Earth system is perceived as being composed of a 'geosphere', 'biosphere', and 'noosphere'. However to apply such a simplified representation of the Earth system, the understanding of the term 'noosphere' is modified compared to its habitual use.

The terms 'biosphere' and 'geosphere' each comprise two categories. On one side, 'biosphere' and 'geosphere' refer to tangible features of the Earth system, namely biotic and abiotic objects that are 
altered in time and space. On the other side, the same terms also refer to time/space-dependent processes that govern the interaction of these tangible features. The habitual understanding of the term noosphere (see for example the discussion by Hamilton and Grinevald [12]), does not refer to time/space-dependent processes that govern the interaction of tangible features. Here, the understanding of the term noosphere is altered to refer to time/space-dependent processes that govern the interaction of tangible features; showing how this alteration impinges on the habitual understanding of the term noosphere requires a discussion that goes beyond the scope of this paper.

Thus to be practical (because the term 'noosphere' will be used jointly with the terms biosphere and geosphere to describe the Earth systems), the term 'noosphere' should also refer to the two categories of 'tangible features' and 'processes'. To that end and for the first category, the term noosphere shall refer in the following to the ensembles of the artifacts that are made by people, such as engineered systems for production and consumption. Regarding the second category, the term noosphere shall also refer to the insights of people about how to use these artifacts, namely how to deploy engineered systems. When altered in this manner, the term noosphere refers to tangible features (artifacts, engineered systems) and processes (the intentional use of these artifacts) that govern their interaction. In turn, the Earth system, including its human part, is understood to be composed of tangible features and processes that govern its interactions. Consequently, a simple description of the Earth system deems possible; 'a kind of hybrid Earth, of nature injected with human will, however responsible or irresponsible that will may have exercised' [12] (p. 68).

In this essay, the notion of 'human niche' refers to the Earth system as appropriated by people through production systems and consumption patterns. Applying that quite anthropocentric perspective of a 'human niche', the labels 'adjusting', 'dovetailing', 'decoupling', and 'modulating' are used to highlight how production systems and consumption patterns are organized (including conservation [13]), that is, engineered. Related narratives are sketched under these labels because they reflect more clearly the perceptions that shape the related story-lines than does other labeling, as for example 'adjustment' (to climate change), 'mitigation' (of climate change), 'eco-modernism', and 'geo-engineering', respectively.

In this essay, the term 'people' is used in the plural form instead of terms like humankind, because it refers more intuitively to the multiplicity of human actors, their various alliances, and their interactions; see Barry and Maslin [14] for a discussion. Likewise, the term 'narratives' is used in the plural form, referring to a multitude of 'lay public's story-lines' about things that matter for people.

\subsection{Engineering a Human Niche and Its Narratives}

People are altering the Earth at an accelerating pace. Economic activity and related engineered systems intersect with the planetary biogeosphere in a substantial manner [15-21]. Since at least the industrial revolution, the globe has been stamped with people's activities [22,23], people vigorously applying engineering science, and geosciences. It can be argued that since the onset of agriculture in the Neolithic age, engineering has been an all-purpose activity to shape the 'sociocultural-ecological niches' of people [24-26] for the purpose of maintaining their well-being, mutual care, and reproduction.

Examples to illustrate this perspective are numberous. Civil engineering builds visible intersections of the geosphere and economic activities, for example, dredging a waterway, building a bridge, constructing a hydroelectric power plant, and other more subtle geomorphological changes [27]. A less visible intersection is the design of production systems and consumption patterns that couple human activity and the biogeosphere through fluxes of matter and energy. Urban dwellings may serve as a further example; they constitute a visible intersection with the biogeosphere and they are coupled with the biogeosphere through massive fluxes of matter and energy. For example, cities are receiving drinking water and ejecting waste water, receiving electric power or fuels and ejecting heat, receiving food and ejecting manufactured goods that at the end of their life-cycle are discarded or recycled elsewhere on the globe. The accumulated impacts of engineering production systems and consumption patterns, undertaken to sustain a human population of 9 to 11 Billion people by the end of the century, led to 
effective terra-engineering [15-23,28,29]. Geo-engineering climate processes would be an additional engineering activity; of a similar quality as the modification of the global nitrogen cycle since the development of the Haber-Bosch process at the beginning of the 20th century [29].

Individual and public responses to the self-inflicted alterations of Earth's systems are varied. They include, for example, 'fatalist views' or 'cognitive dissonance' [30,31], as manifested in doomsday scenarios and the denial of global change. Addressing people's concerns appropriately requires shaping their discourses [32], which is a prerequisite for governing 'weird(ing) power relations enlivened by times of radical uncertainty' [33] (p. 10). Such a discourse must be non-expert; it must involve people's preferences and worldviews, and thus it should be a lay-person's narrative.

People's express their preferences and worldviews through both their lifestyles and the design and operation of production systems and consumption patterns. The latter in turn shapes the intersection of societies with the biotic and abiotic environments [34]. Whatever shape intersections may take in view of the scientific-technical means and economic resources, what is essential for the decision taking will be people's worldviews, their preferences regarding their lifestyles, and their values. People's references and values are shaped by and expressed through their narratives [35], for example, narratives about the purpose of actions and views about 'what is right'. Communication that does not entail expert knowledge and that is close to the lay public's terms will enable laypersons to argue their choices. Narratives offer such kind of communication.

\subsection{Applied Geosciences and Engineering}

Societies abundantly apply geoscience knowledge for their economic activities [36]; for example, our knowledge and know-how about the features of rock, soil, water, and air is needed for the production of goods, extraction of minerals, laying foundations for buildings, or managing floodplains. Likewise, the understanding of the biogeosphere is built into many engineered systems; for example, for transport and energy systems, for dwellings and irrigation systems, for the capture of drinking water and evacuation of excess water, for the treatment of household waste and controlling emissions from combustion engines, or for operating radio connections when solar storms hit the Earth.

The engineering of systems is habitually undertaken in a double framework. The first contains scientific-technological means, which can be deployed within the available economic resources. The second shapes narratives specifying what the engineered systems shall deliver [37-40]. The construction and operation of an 'engineered system' relates people's activities to the natural systems. The 'engineering narrative' frames this work with purpose and shapes people's design of their sociocultural-ecological niche.

The design of an engineered system as well as its specific operation procedures depend on natural and technical constraints, on economic means, and on societal choices. For example, the design of the high-water spillway of a hydroelectric power plant applies the laws of hydrodynamics, and the retention of water in the lake behind the dam is managed by the function of the hydrological regimes, the intended use of water downstream of the power plant, and the needs of the society for electrical power [41].

The design and operation of an engineered system in the first instance is about the appropriation of resources, namely value-driven choices to allocate opportunities. Consequently, the engineering of the intersections of people's activities and the biogeosphere are as much a reflection of value systems, cultural choices, lifestyles, virtue, and worthwhile courses of action [42], as they are of scientific-technical choices in geo- and engineering sciences.

Anthropogenic climate change is the most prominent example of the composed aspect of applied geosciences and engineering. The history of engineering provides many other examples on a smaller scale, such as damming rivers for hydro-electrical power generation or irrigation [43-46]. In all these cases, experts, politicians, and lay-persons use theories and facts, discuss uncertainties and hazards, and consider responsibilities and benefits for them, other people, and other generations [47-49]. The discourses of these debates draw on vocational training, shared experiences, common sense, 
general education, or world-views. Although expert-knowledge in geoscience and engineering is an inherent part of these discourses, it is embedded in a wider scope of knowledge, expertise, governance, and lifestyle choices $[50,51]$.

\subsection{Intersections, Iterations, and Narratives}

Regarding narratives about Earth' systems, three aspects can be summarized in a succinct manner: (1) people are a kind of 'species of engineers' that carve out their ecological niche from the biogeosphere [25,26]; (2) '[People] consist of abstract information, including the distinctive ideas, theories, intentions, feelings and other states of mind that characterize [an ' $I$ '] ' them [52] (p. 130) and shapes their mental models [53] or 'memes', that is, insights shared among people [54]; and (3) people conceive engineered systems through the sharing of insights [55-60].

Drawing on the above and describing the philosophical view that is underpinning this essay: (i) the term 'memes' denotes the shared insights of people (e.g., 'what economic activities shall be undertaken', or 'what engineering of systems shall be endeavored') that aggregate experiences, know-how, world-views, values, preferences, etc.; (ii) the term 'noosphere' denotes the ensemble of shared insights of people and the related tangible artifacts (engineered systems); (iii) the term 'earth system dynamics' denotes the dynamics of each of the three spheres (noo-, bio-, and geosphere) including their intersections; and (iv) the term 'engineering' denotes the specific activity by which people make artifacts that intersect the noosphere and the biogeosphere.

Anthropocentric global change habitually is not discussed as an 'engineered system', although it is engineering of unprecedented complexity. While complexity makes achieving agreements a more complicated process, the process itself is known. When applying engineering sciences and geosciences to shape an economy, people then also conceive how to operate the intersections of their activities with the biogeosphere [61-64]. Considering earth systems dynamics, which are non-linear with feed-backs, an iterative path-dependent decision progress may be appropriate [65]. The systemic difficulties of forecasting the behavior of non-linear systems with feed-backs favors path-dependent iterative decision making [66], which should be supported by a guiding story-line, that is, a narrative about general purpose.

\section{Narratives for Engineering a Human Niche}

Drawing on the perspectives that are outlined above, the following section presents in an illustrative manner four tales on how production systems and consumption patterns may be organized for engineering a human niche. The tales are labeled 'adjusting', 'dovetailing', 'decoupling', and 'modulating'. The subsequent section then presents a scheme to characterize these tales.

\subsection{An Introduction to Four Tales}

The first tale is called 'adjusting'. It is about engineering that handles hazardous side effects (collateral impacts) of the production systems and consumption patterns. This 'adjusting engineering narrative' tells the baseline story-line of industrialized societies; for example, refitting exhaust-pipes to wash and filter fumes. Collateral impacts (as well as hazards) are perceived as external factors under which given production systems and consumption patterns have to continue to function. The plans to adjust sea-defenses to match the expected regional sea-level rise $[67,68]$ provide an example in the context of handling climate change.

The second tale is called 'dovetailing'. It is about engineering that incrementally alters production systems and consumption patterns in a manner in which anthropogenic fluxes of matter and energy merge with natural fluxes. The Montreal Protocol for the abatement of stratospheric ozone depleting substances illustrates this kind of 'dovetailing engineering narrative'. A particular production system and consumption pattern was modified by means of an intergovernmental agreement [69-72].

The third tale is called 'decoupling'. It is about engineering that segregates production systems and consumption patterns from natural systems. Such engineering is a frequent practice at the local scale; 
e.g., sealed dumps for waste or closed systems for the industrial use of water. Such an approach for the decoupling of natural and human spheres at a planetary scale is promoted as 'eco-modernism' [73]: a stable global population is living mainly as urbanized societies using nuclear power and closed fluxes of matter. This 'decoupling engineering narrative' emphasizes that 'culture' is distinct from 'nature'.

The fourth tale is called 'modulating'. It is about engineering that modulates planetary processes of the biogeosphere $[2,29,74]$. This 'modulating engineering narrative' emphasizes activities to adapt 'nature' to 'culture' so that the environment suits people's appropriation. From prehistoric times, people have, of course, engineered environments to their needs; through for example, slash and burn agriculture, irrigation agriculture in semi-deserts, or future ocean fertilization to capture excess carbon dioxide.

These four narratives easily coincide with peoples' endeavors over the last few centuries to engineer production systems and consumption patterns [75]. Accordingly, the respective narratives are known, and they were applied in various configurations [63], and thus it seems to make sense to apply them now on a planetary scale. The related 'engineering business-case' would evolve in a known manner: (i) the available technological means, scientific understanding, and economic resources together determine what efforts are feasible; (ii) within these limits, worldviews, values, and preferences determine the choices that are made by decision makers; and (iii) related ethical choices are similar to conventional professional contexts.

\subsection{Schematized Narratives}

To frame the narratives that were outlined in the previous section, six features are selected to describe an ideal-type engineered system. These features (i) are molded to be bipolar; (ii) describe generic aspects; (iii) do not rely on specific scientific-technical expertise; and (iv) tag narratives with a specific profile of people's preferences and views. By construct (that is, setting an ideal-type scheme), these features are describing end-points of a more messy reality. Real world examples may fall incompletely into one or the other of these opposing pairs of description.

1 First feature, 'end versus start': This generic aspect regards the 'intervention point' of the engineered systems. As in pollution control, it is distinguished between engineering 'at the start of the pipe' (that is, to tackle root-causes) or 'at the end of the pipe' (that is, to tackle consequences). When applied to engineering a human niche, then a first bipolar feature can be discriminated, namely whether engineering tackles a cause within the production systems and consumption patterns or an effect within the biogeosphere. An example for such a choice is: whether to clean the seas of plastic discard or to restrict the use of plastic bags on land [76].

2 Second feature, 'regional versus global': This generic aspect regards the societal process of 'consensus finding'. Consensus about a particular engineered system is important because engineering can be effective only if the relevant stakeholders are supportive [77-80]. When applied to engineering a human niche, then a second bipolar feature can be discriminated, namely whether consensus for an engineered system has to be found 'regionally' (that is, the consensus of limited scope and complexity including a limited geographical extent) or has to be found 'globally'. An example is given by the issue of how to regulate the use of sulfur-rich fuels for ships: on a harbor by harbor basis, on a regional-sea level, or at the world-shipping level [81,82].

3 Third feature, 'to-respond versus to-shape': This generic aspect regards peoples' opinion about what human beings can achieve; namely of what is the nature of the 'human agency' [83-89]. This aspect distinguishes engineered systems by people's understanding of how they may act when an event affects their ways of living, producing, or consuming. When applied to engineering a human niche, then a third bipolar feature can be discriminated, namely whether people perceive themselves as a 'responding agent' or a 'shaping agent'. A 'responding agent' perceives the event as impacting from outside, that is to be 'external', and the 'responding agent' tries to restrain the impact of this external event. A 'shaping agent' perceives the same event as something that results from its own way of operating. Consequently, the 'shaping agent' re-engineers its operations. 
An example for a 'responding agency' are the plans to strengthen shore defenses along the coast of the North Sea $[90,91]$ in reaction to sea-level rise that is caused by global warming; a 'shaping agency' would curb greenhouse gas emissions that cause global warming.

4 Forth feature, 'culture-and-nature versus culture-or-nature': This generic aspect regards people's understanding of the concepts of 'nature' and 'culture' and the mutual relation between both concepts [92-98]. When applied to engineering a human niche, then a forth bipolar feature can be discriminated, namely whether people understand the concepts of 'nature' and 'culture' to prescribe two well disconnected realms of structures, processes, and categories, or as one interconnected realm. Depending on the respective understanding, the justification for engineered systems differ, namely regarding what is an ethical manner in which to intervene in the biogeosphere. Examples for such a choice are the engineering projects to transfer water between different river basins [99].

5 Fifth feature, 'to-preserve versus to-discount': This generic aspect regards how past investments are assessed [100]. An investment may be of a cultural, social, or economic nature and may be made to secure either inputs or outputs; however for this essay, these investments of a different kind are lumped together because of their common aspects: (i) the investments concern the living conditions of people, (ii) efforts had been undertaken to make them, and (iii) early discounting of investments is a loss. When applied to engineering a human niche, then a fifth bipolar feature can be discriminated, namely whether engineered systems preserve the stockpile of investments or are disruptive. Thus, a distinction is made regarding the effect that deploying a particular engineered system may have for preserving or altering cultures, lifestyles, and the economy. An example of such an engineered system is the construction of the Aswan Dam, that among its benefits and collateral effects included the deliberate displacement of some historical monuments; while other monuments got drawn [101,102].

6 Sixth feature, 'innovative versus known': This generic aspect regards the risk appetite that is implicit to the choice of the engineered systems and the involved technology options. A distinction is made whether a technology option is 'innovative' or 'established'. When applied to engineering a human niche, then a sixth bipolar feature can be discriminated, namely whether the engineered systems deploy established technologies (or their incrementally improved variants) or whether new (even disruptive) technologies are used. An example is the recent choice to alter Germany's energy mix, namely to phase out nuclear power and to strengthen renewable energies [103]. This choice prefers, instead of using established nuclear power technology and accepting its 'known' risks (such as: impact of accidents, long-term storage of radioactive substances), to use an emerging innovative technology. At the time of the decision of the German government to alter Germany's energy mix, it was not proven that the technology-mix for renewable energies could provide the energy supply for an industrialized society.

To compact the description, the six features can be combined to three pairs of related but not tied features: (i) the consensus about an effective intervention (features 1, 2), (ii) the philosophical notions about what people can do (features 3,4 ), and (iii) the discernment of loss and uncertainty (features 5, 6). These three sets can be described as: (i) 'whether consensus is sought to tackle problems globally at their origin or to address them at selected regional points of impact'; (ii) 'whether people respond to external factors or shape environments through design of their production systems and consumption patters'; (iii) 'whether past investments (cultural, social, economic) are discounted in favor of innovative means (technologies, lifestyle, business model)'.

Using the frame that was developed above, four variants to engineer a human niche can be described and the associated narratives can be tagged: 


\subsubsection{Scheme: 'Adjusting'}

The 'adjusting scheme' implies a course of action having the ideal-type tags: (i): 'tackles problems at their regional point of impact'; (ii) 'responds to external factors'; and (iii) 'preserves past investments through the use of known technologies'.

The 'adjusting scheme' is about offsetting undesirable events, e.g., global change, which are perceived as external conditions under which production systems and consumption patterns shall continue to function. Consequently, the purpose of engineering is to complement their design, if needed iteratively. The 'adjusting scheme' views 'nature' as a stage of external factors to which people's agency responds to safeguard 'culture'.

An example for the 'adjustment scheme' is the handling of storm surges in the harbor of Hamburg [104]. The Elbe River downstream from Hamburg got dredged so that big ships can reach the harbor that is situated about $100 \mathrm{~km}$ upstream of the mouth of the Elbe estuary. After dredging, storm surges can also propagate more effectively through the deeper river channel and flooding risks increase in Hamburg. Therefore the river dykes have been raised. A relocation of the harbor (or part of it) to the mouth of the estuary of the Elbe River was not an option although a new deep-water harbor, the 'Jade-Weser-Port', is being developed $150 \mathrm{~km}$ to the west at the Jade River [105]. Operating the 'Hamburg Harbor' at its current location and dredging the Elbe River was the option of 'business as usual'. It kept production patterns and Hamburg's political and cultural standing of a 'first class' harbor. The German Land Hamburg preserved investments, applied known technologies (building dykes), and found local consensus for an action that was tackling the external factor (raising storm surges) 'at the end of the pipe'.

Thriving of the 'adjusting scheme' implies (i) incremental modification of proven structures and processes, (ii) skills to forecast changes on timescales longer than the renewal period of the engineered system, and (iii) regional consensus to tackles problems 'at the end of the pipe'. The 'adjusting scheme' is convenient to handle niche building, because (i) it is conservative in terms of its intrinsic choices as long as it is compatible with the available means and resources, and (ii) it sticks to the intrinsic development paths of societies so that the accumulated economic, social, and cultural value is not depreciated.

\subsubsection{Scheme: 'Dovetailing'}

The 'dovetailing scheme' implies a course of action having the ideal-type tags: (i): 'global consensus to tackle problems at their origin'; (ii) 'shaping environments through modification of production systems and consumption patterns'; and (iii) 'discounting past investments and the use of innovative technologies'.

In view of many actors, global changes should be mastered by 'greening' of the economy, i.e., incrementally altering production systems and consumption patterns. The general objective of a 'dovetailing scheme' would be to merge re-engineered anthropogenic and natural fluxes of matter and energy.

The abatement of stratospheric ozone depleting substances provides an illustration of such an engineering approach. An identified production system and consumption pattern was modified step-wise 'at start of the pipe' by intergovernmental agreement. The modifications are implemented by political, social, and economic practices, which previously were developed to curb regional pollution. The decreasing stratospheric ozone concentrations did not trigger the 'adjustment concept' as the main mode of response, namely protection against UV radiation [106]; even though the Cancer Council Australia [107] is campaigning against sun bathing.

The 'dovetailing scheme' is convenient to handle niche building, because: (i) it is moderately constraining because the pace of the incremental modifications of production systems and consumption patterns is negotiated among the stakeholders; (ii) the scheme has historical precursors in the societies in transition to the industrial revolution $[63,108]$; and (iii) the political and social processes to find 
consensus are tested $[17,109]$, although they need time [110], such as agreeing on the successor to the Kyoto Protocol.

Applying the 'dovetailing scheme' implies understanding why altered local dynamics of the biogeosphere is a consequence of human agency (that is, production and consumption) and therefore could be countered at the 'start of the pipe'. The 'dovetailing scheme' requires skills to observe the changes of complex systems [111], to appropriately adjust the production systems and consumption patterns, and to identify responses that are only moderately disruptive.

\subsubsection{Scheme: 'Decoupling'}

The 'decoupling concept' implies a course of action having the ideal-type tags: (i): 'global consensus to tackle problems at their origin'; (ii) 'shaping environments through the choice of production systems and consumption patterns'; (iii) 'preserving past investments through the use of known technologies'.

The 'decoupling scheme' ('eco-modernism') is about how to sever fluxes of matter due to natural processes from fluxes of matter due to production systems and consumption patterns [73,96,112]. To this end, people are seen as shaping agents for the cultural space at 'the start of the pipe': a massively urbanized society of a stable global population using nuclear power to keep matter cycling within the economy. 'Culture' is seen as distinct from 'nature'; the latter provides a stage for people's activities that are concentrated in metropolitan areas.

The approach 'to decouple' reflects the traditional purpose of engineered systems of industrialized societies, namely to gain independence from natural processes. This development path is preserving investments into current cultural and social orientations. Thus to handle niche building, the 'decoupling scheme' is non-disruptive. In this sense, it is 'conservative' [57,113]; a choice that, however, is not made for all technological options that are advocated for.

\subsubsection{Scheme: 'Modulating'}

The 'modulating scheme' implies a course of action having the ideal-type tags: (i): 'global consensus to tackle problems at their point of impact'; (ii) 'responding to external factors'; (iii) 'preserving past investments through innovative technologies'.

The 'modulating scheme' (including 'geo-engineering' in it habitual sense) is about how to alter the Earth's physical and bio-geological systems $[114,115]$ to off-set at the 'end of the pipe' the side-effects of people's activities. People's agency may alter the biogeosphere ('nature') to fit to people's 'culture'. The purpose of engineering is to keep environments suitable for appropriation through altering natural processes at a global scale using new technologies [116]; for example, ocean fertilization to capture excess carbon dioxide.

Applying the 'modulating scheme' to handle niche building means to stick to the current development paths of societies, thus keeping the production systems and consumption patterns unchanged and the bulk of the accumulated economic, social, and cultural value not depreciated $[2,29,117-120]$.

\section{From Engineering Schemes to Engineering Narratives}

The main differences of the four schemes 'to engineer global change' are tagged by a set of features.

- The tags of the 'adjusting scheme' are: end of pipe control, regional consensus, responding agency, culture-nature dichotomy, preserving investments, and known technologies.

- The tags of the 'modulating scheme' are: end of pipe control, global consensus, responding agency, culture-nature dichotomy, preserving investments, new technologies.

- The tags of the 'decoupling scheme' are: start-of-the-pipe control, global consensus, shaping agency, culture-nature dichotomy, discounting investments, known technologies.

- The tags of the 'dovetailing scheme' are: start-of-the-pipe control, global consensus, shaping agency, culture-nature continuum, discounting investments, new technologies. 
Thus, each scheme 'to engineer global change' is described by a specific binary profile. By construct, these profiles do not require much understanding of particular scientific-technical or economic matters. However, this binary description has its limitations. It leads to a coarse description and schematic assignment of features. Also, the bipolar features do not form an orthogonal metric, otherwise more schemes would be plausible (six binary features could label sixty-four schemes). In spite of these limitations, elements for specific narratives can be sketched.

The 'decoupling scheme', the 'modulating scheme', and the 'dovetailing scheme' match to narratives about altering Earth systems dynamics, although in different spheres. In opposition to them, the 'adjusting scheme' matches to a narrative about measures at a regional level to preserve past investments (economic, social, and cultural). Its particular political baseline regarding production systems and consumption patterns is 'business as usual'. The biogeosphere is perceived as a kind of stage for people's activities, the cumulative impact on the biogeosphere of people's activities is recognized, and that effect is factored into the next generation of engineered systems deployed at the regional level.

The narratives of the 'modulating scheme' and the 'decoupling scheme' refer to the traditional development paths of globalized industrial societies, namely either to alter 'nature' or to sever 'culture' from 'nature'. The two schemes differ about which part of Earth systems dynamics should be altered, namely whether the engineering targets either the biogeosphere ('modulating scheme', e.g., geo-engineering) or the noosphere ('decoupling scheme', e.g., eco-modernism).

The 'modulating narrative' applies a non-dichotomous view of nature and culture. It is about engineering the biogeosphere to preserve past investments (economic, social, and cultural) because that seems feasible, at least as a 'hot-fix', given the resistances to changes of lifestyles, production systems, or consumption patterns. Thus, the political baseline regarding production systems and consumption patterns is consenting to 'business as usual'. The 'decoupling narrative' is applying a dichotomous view of nature and culture [112], and it is explicit about engineering the noosphere (the artifacts such as built-up environments, production systems, and the related 'memes'). In an ecomodernist's vision, nature is the stage for highly urbanized environments of relatively limited geographical extend that are mainly powered by nuclear energy, and that operate closed cycles of fluxes of matter.

The 'adjusting narrative' and the 'modulating narrative' both present an approach to preserve past investments by deploying technologies in the biogeosphere that shall counter the collateral effects of human activity ('culture') that impact on 'nature'. The 'adjusting narrative' is about how to cope regionally with the effects of external global factors. The 'modulating narrative' is about action with a global scope.

The 'dovetailing narrative' and the 'decoupling narrative' both present an approach to reduce the root causes for global change within the production systems and consumption patterns and to preserve past investments as far as compatibility with that approach. Both narratives differ on how to perceive the relation of 'nature' and 'culture' and what kind of innovative engineering (technologies) are chosen; namely 'deploying emerging technologies', respectively 'deploying a subset of available technologies on a larger scale'. The 'dovetailing scheme' matches to a narrative about an incremental modification of the noosphere, namely the current societal development paths for production systems and consumption patterns. Consequently, some discounting of past investments is foreseen and a 'global start-of-the-pipe dovetailing engineering concept' is introduced step-wise. The recent agreement on the replacement of the Kyoto Protocol gives a prominent example for that choice and the difficulties towards achieve it.

A grouping of narratives emerges; the 'adjusting narrative' and the 'dovetailing narrative' set the main alternative. The key-difference between them are substitute choices for three features: 'where to put controls' (end/start of the pipe), 'what consensus is needed for effective engineered systems' (regional/global), and 'whether to keep business as usual' (preserve/discount investments of the past). Both narratives have a close neighbor, the 'modulating narrative' and the 'decoupling narrative', 
respectively. The distinction of the main narrative to the respective neighboring narrative is mainly by the technology choice, namely the 'innovativeness' of the deployed technology.

Whatever narrative will support a specific 'engineered system' will reflect on people's preferences and worldviews. Therefore, the protagonists of each concept argue what is ethically (philosophically) 'right'; for example, see the 'Ecomodernist Manifesto' [73] in support of the 'decoupling narrative' or the 'Oxford Principles' [120] in support of the 'modulating narrative' (geoengineering), notwithstanding the mainstream political advocacy for a mix of the 'adjusting narrative' and 'dovetailing narrative'. These ethical discourses go beyond argumentation of the protagonists of what seems to them sound engineering, economic feasibility, and acknowledged social complexity.

Within the ideal-type schemes presented here, simple positioning for each of the six generic features identifies the retained scheme to 'engineer global change'. To illustrate, a preference for a 'start of the pipe' engineering approach excludes the 'adjusting' and 'modulating' schemes, implies accepting discounting of past investments, and offers 'decoupling' as an option. Such findings may be an outcome that is not liked. Notwithstanding how this contradiction is handled, it is about values and preference, thus matters about which people can engage without recourse to technical or scientific experts.

\section{Summary and Conclusions}

People have built an 'anthropocentric biogeosphere' or 'cultural niche' through engineering their environments with the purpose of sustaining their existence and reproduction [121].

Initially, the biological evolution of the human species came in pair with tool-making capacity and social organization [122]. Early agricultural societies with urban centers (for example Uruk, 3000 BC) already engineered water supply for irrigation purposes [123], Rome's harbor Portus was engineered for limiting siltation [124], and the adaptation of agriculture systems to climate variations could be engineered during the Renaissance [125]. Building on such early experiences, people massively extended what they knew how to engineer by applying geoscience know-how.

Nowadays, people influence planetary fluxes of matter and energy, linking so profoundly the matters of social, cultural, and political nature with features of the planetary biogeosphere [20,126-128]. Evidently, taking the number of people as a metric, this 'terra-engineering by applied geosciences' qualifies as being rather prosperous; although with negative impacts for some people [23] and with risks for the future [129-131]. Therefore the lay-public should participate effectively in choices that lead to the particular design of 'engineered systems' for producing, distributing, and consuming goods and services. The diversity and complexity of the technological means and scientific insights sets an entry barrier for many.

The history of engineering an anthropocentric biogeosphere exhibits complex social and cultural processes, as illustrated for the Americas by Denevan [132,133], for the US by Purdy [59], for France by Fressoz [63], and by Chew and Sarabia [97] or Kowarsch [51] for a long historical period or philosophical context, respectively. Nowadays, as anthropogenic global change is intentional and massive, narratives shall capture social and cultural features, such as the preferences of people, their world-views, and shall reflect general purpose (e.g., [4,35,46,49,58,95,134]). Such narratives extend the discussions between specialists beyond the respective realms of professional competence and influence the engineering of the production systems and consumption patterns. Yet, insight into social and cultural processes is also an entry barrier for many.

This essay illustrates how entry barriers may be lowered, when ideal-type features are found that describe schemes 'to engineer global change'. The six features that are proposed are not simple because they involve abstraction. Yet, their essence can be understood without a specialist's education and as such offers engagement. To that end, it is sketched how the narratives can be derived from a simple juxtaposition of six ideal-type features, which relate to the four schemes 'to engineer global change'. These schemes differ regarding the choices of societal development paths, the kind of technology options that are preferred, the social-cultural complexity that has to be accounted for, and the world 
views that justify decisions. The respective narratives do not require expert insights and can be used by non-specialists, i.e., lay-public to do both, to settle with a narrative that fits to choices, and to enrich the narrative with further considerations.

Applying the discourse of this essay, the current public policies to regulate production systems and consumption patterns favored a mix of 'adjusting' and 'dovetailing' schemes, because currently it is economical and technically feasible to subdue the impact of anthropogenic climate change. The 'decoupling narrative' or 'modulating narrative' do not play a noticeable public role, yet approaches on 'how to geoengineer the planet' are considered (e.g., $[29,33,114,118,135]$ ) including ways on how to act in the absence of public consent. The expected anthropogenic global change (e.g., $[136,137])$ will likely put into question the current mix of public action. Consequently, future Earth System Governance $[50,138]$ has to tackle more fluently than today the known but complex and value-loaded scientific, technical, and economic issues (such as: whether science and technology is professionally 'sound', how to address responsibility for past emissions, distribution of poverty and wealth, access to resources, or opportunities for more sustainable development for some). In that situation, the laypersons' involvement in decisions [139,140] will be much needed for effectively engineering global change. Any democratic decision process in (then) possibly confusing times and governance acting in the context of bounded reality [141] will possibly need 'lay-public's engineering story-lines' that are part of peoples' perceptions (memes) [30] and will support the long-winded iterative process $[65,66,142]$ to consciously alter both the biogeosphere and the noosphere [12].

Acknowledgments: The author is grateful to his employer who granted my following extracurricular activities that lead to this essay. All views expressed herein are entirely of the author, do not reflect the position of the European Institutions or bodies and do not, in any way, engage any of them.

Conflicts of Interest: The author declares no conflict of interest.

\section{References}

1. Allen, T.F.; Giampietro, M.; Little, A. Distinguishing ecological engineering from environmental engineering. Ecol. Eng. 2003, 20, 389-407. [CrossRef]

2. Bellamy, R.; Chilvers, J.; Vaughan, N.E.; Lenton, T.M. “Opening up” geoengineering appraisal: Multi-Criteria Mapping of options for tackling climate change. Glob. Environ. Chang. 2013, 23, 926-937. [CrossRef]

3. Kleinhans, M.G.; Buskes, C.J.J.; de Regt, H.W. Philosophy of Earth Science. In Philosophies of the Sciences; Wiley-Blackwell: Oxford, UK, 2010; pp. 213-236.

4. Phillips, J. Storytelling in Earth sciences: The eight basic plots. Earth-Sci. Rev. 2012, 115, 153-162. [CrossRef]

5. Langmuir, C.; Broecker, W. How to Build a Habitable Planet; Princeton University Press: Princeton, NJ, USA, 2012.

6. Helbing, D. Globally networked risks and how to respond. Nature 2013, 497, 51-59. [CrossRef] [PubMed]

7. Head, B.W.; Alford, J. Wicked problems: Implications for public policy and management. Adm. Soc. 2015, 47, 711-739. [CrossRef]

8. Pollitt, C. Debate: Climate change-The ultimate wicked issue. Public Money Manag. 2016, 36, 78-80. [CrossRef]

9. Schmidt, J.J.; Brown, P.G.; Orr, C.J. Ethics in the Anthropocene: A research agenda. Anthropocene Rev. 2016, 3, 188-200. [CrossRef]

10. Hamilton, C. The Commonwealth and sea-level rise. Round Table 2003, 92, 517-531. [CrossRef]

11. Gibson-Graham, J.K.; Roelvink, G. An economic ethics for the Anthropocene. Antipode 2012, 41, $320-346$. [CrossRef]

12. Hamilton, C.; Grinevald, J. Was the Anthropocene anticipated? Anthropocene Rev. 2015, 2, 59-72. [CrossRef]

13. Wilson, E.O. Half-Earth—Our Planet's Fight for Life; Norton \& Company: New York, NY, USA, 2016.

14. Barry, A.; Maslin, M. The politics of the anthropocene: A dialogue. Geo Geogr. Environ. 2016, 3, e00022. [CrossRef]

15. Ellis, E.C.; Goldewijk, K.K.; Siebert, S.; Lightman, D.; Ramankutty, N. Anthropogenic transformation of the biomes, 1700 to 2000. Glob. Ecol. Biogeogr. 2010, 19, 589-606. [CrossRef]

16. Ellis, E.C. The Planet of No Return Human Resilience on an Artificial Earth. Breakthr. Inst. 2011, 2, 37-44. 
17. Ellis, E.C. Anthropogenic transformation of the terrestrial biosphere. Philos. Trans. R. Soc. A 2011, 369, 1010-1035. [CrossRef] [PubMed]

18. Barnosky, A.D.; Hadly, E.A.; Bascompte, J.; Berlow, E.L.; Brown, J.H.; Fortelius, M.; Getz, W.M.; Harte, J.; Hastings, A.; Marquet, P.A.; et al. Approaching a state shift in Earth's biosphere. Nature 2012, 486, 52-58. [CrossRef] [PubMed]

19. Monastersky, R. Anthropocene: The human age. Nature 2015, 519, 144-147. [CrossRef] [PubMed]

20. Zalasiewicz, J.; Waters, C.N.; Williams, M.; Barnosky, A.D.; Cearreta, A.; Crutzen, P.; Ellis, E.C.; Ellis, M.A.; Fairchild, I.J.; Grinevald, J.; et al. When did the Anthropocene begin? A mid-twentieth century boundary level is stratigraphically optimal. Quat. Int. 2015, 383, 196-203. [CrossRef]

21. Waters, C.N.; Zalasiewicz, J.; Summerhayes, C.; Barnosky, A.D.; Poirier, C.; Galuszka, A.; Cearreta, A.; Edgeworth, M.; Ellis, E.C.; Ellis, M.A.; et al. The Anthropocene is functionally and stratigraphically distinct from the Holocene. Science 2016, 351, aad2622. [CrossRef] [PubMed]

22. Braje, T.J.; Erlandson, J.M. Looking forward, looking back: Humans, anthropogenic change, and the Anthropocene. Anthropocene 2013, 4, 116-121. [CrossRef]

23. Lewis, S.L.; Maslin, M.A. Defining the Anthropocene. Nature 2015, 519, 171-180. [CrossRef] [PubMed]

24. Foley, S.F.; Gronenborn, D.; Andreae, M.O.; Kadereit, J.W.; Esper, J.; Scholz, D.; Pöschl, U.; Jacob, D.E.; Schöne, B.R.; Schreg, R.; et al. The Palaeoanthropocene-The beginnings of anthropogenic environmental change. Anthropocene 2013, 3, 83-88. [CrossRef]

25. Ellis, E.C. Ecology in an anthropogenic biosphere. Ecol. Monogr. 2015, 85, 287-331. [CrossRef]

26. Fuentes, A. The extended evolutionary synthesis, ethnography, and the Human Niche: Toward an integrated anthropology. Curr. Anthropol. 2016, 57, S13-S26. [CrossRef]

27. Brown, A.G.; Tooth, S.; Bullard, J.E.; Thomas, D.S.G.; Chiverrell, R.C.; Plater, A.J.; Murton, J.; Thorndycraft, V.R.; Tarolli, P.; Rose, J.; et al. The geomorphology of the Anthropocene: Emergence, status and implications. Earth Surf. Processes Landf. 2016, 42, 71-90. [CrossRef]

28. Schwägerl, C. The Anthropocene-The Human Era and How It Shapes Our Planet; Synergetic Press: London, UK, 2014.

29. Morton, O. The Planet Remade-How Geoengineering Could Change the World; Princeton University Press: Princeton, NJ, USA, 2015.

30. Bellamy, R.; Hulme, M. Beyond the tipping point: Understanding perceptions of abrupt climate change and their implications. Weather Clim. Soc. 2011, 3, 48-60. [CrossRef]

31. Steffen, W.; Grinevald, J.; Crutzen, P.; McNeill, J. The Anthropocene: Conceptual and historical perspectives. Philos. Trans. R. Soc. A 2011, 369, 842-867. [CrossRef] [PubMed]

32. Moore, A. Anthropocene anthropology: Reconceptualizing contemporary global change. J. R. Anthropol. Inst. 2016, 22, 27-46. [CrossRef]

33. Sweeney, J.A. Command-and-control: Alternative futures of geoengineering in an age of global weirding. Futures 2014, 57, 1-13. [CrossRef]

34. Bohle, M. Handling of human-geosphere intersections. Geosciences 2016, 6, 3. [CrossRef]

35. Veland, S.; Lynch, A.H. Scaling the Anthropocene: How the stories we tell matter. Geoforum 2016, 72, 1-5. [CrossRef]

36. Srbulov, M. Practical Guide to Geo-Engineering; Geotechnical, Geological and Earthquake Engineering; Springer: Dordrecht, The Netherlands, 2014; Volume 29.

37. Bugliarello, G. Ideal of civil engineering. J. Prof. Issues Eng. Educ. Pract. 1994, 120, 290-294. [CrossRef]

38. Sternberg, R. Hydropower: Dimensions of social and environmental coexistence. Renew. Sustain. Energy Rev. 2008, 12, 1588-1621. [CrossRef]

39. Dresp-Langley, B. Dimensions of environmental engineering. Open Environ. Eng. J. 2008, 1, 1-8. [CrossRef]

40. Fu, B.; Wang, Y.K.; Xu, P.; Yan, K.; Li, M. Value of ecosystem hydropower service and its impact on the payment for ecosystem services. Sci. Total Environ. 2014, 472, 338-346. [CrossRef] [PubMed]

41. Donia, N. Aswan High Dam Reservoir management system. J. Hydroinform. 2013, 15, 1491-1510. [CrossRef]

42. Ehrlich, P.R.; Kareiva, P.M.; Daily, G.C. Securing natural capital and expanding equity to rescale civilization. Nature 2012, 486, 68-73. [CrossRef] [PubMed]

43. Egré, D.; Milewski, J.C. The diversity of hydropower projects. Energy Policy 2002, 30, 1225-1230. [CrossRef]

44. Koch, F.H. Hydropower-The politics of water and energy: Introduction and overview. Energy Policy 2002, 30, 1207-1213. [CrossRef] 
45. Halbe, J.; Adamowski, J.; Pahl-Wostl, C. The role of paradigms in engineering practice and education for sustainable development. J. Clean. Prod. 2015, 106, 272-282. [CrossRef]

46. Schmidt, J.J. Historicising the Hydrological Cycle. Water Altern. 2014, 7, 220-234.

47. Amundsen, H.; Berglund, F.; Westskog, H. Overcoming barriers to climate change adaptation-A question of multilevel governance? Environ. Plan. C Gov. Policy 2010, 28, 276-289. [CrossRef]

48. Krauss, W. Anthropology in the Anthropocene: Sustainable development, climate change and interdisciplinary research. In Grounding Global Climate Change. Contributions from the Social and Cultural Sciences; Springer: Dordrecht, The Netherlands, 2015; pp. 59-76.

49. Hutchings, J.A.; Stenseth, N.C. Communication of Science Advice to Government. Trends Ecol. Evol. 2016, 31, 7-11. [CrossRef] [PubMed]

50. Biermann, F. The Anthropocene: A governance perspective. Anthropocene Rev. 2014, 1, 57-61. [CrossRef]

51. Kowarsch, M. A Pragmatist Orientation for the Social Sciences in Climate Policy; Boston Studies in the Philosophy and History of Science; Springer International Publishing: Basel, Switzerland, 2016; Volume 323.

52. Deutsch, D. The Beginning of Infinity; Penguin Books: London, UK, 2011.

53. Jones, N.A.; Ross, H.; Lynam, T.; Perez, P.; Leitch, A. Mental Model: An Interdisciplinary Synthesis of Theory and Methods. Ecol. Soc. 2011, 16, 46. [CrossRef]

54. Pagel, M. Wired for Culture Origins of the Human Social Mind; Norton \& Company: New York, NY, USA, 2012.

55. Taschdjian, E. The sociotectonics of the Noosphere. J. Gener. Philos. Sci. 1989, 20, 106-115. [CrossRef]

56. Ellis, M.A.; Trachtenberg, Z. Which Anthropocene is it to be? Beyond geology to a moral and public discourse. Earth's Future 2014, 2, 122-125. [CrossRef]

57. Dalby, S. Framing the Anthropocene: The good, the bad and the ugly. Anthropocene Rev. 2015, 3, 1-19. [CrossRef]

58. Latour, B. Face à Gaia Huit Conférences sur le Nouveau Régime Climatique; Éditions La Découverte: Paris, France, 2015.

59. Purdy, J. After Nature: A Politics for the Anthropocene; Harvard University Press: Cambridge, MA, USA, 2015.

60. Hamilton, C.; Bonneuil, C.; Gemenne, F. The Anthropocene and the Global Environmental Crisis: Rethinking Modernity in a New Epoche; Routledge: London, UK, 2015.

61. Landes, D.S. The Unbound Prometheus; Cambridge University Press: Cambridge, UK, 2003.

62. Malanima, P. Europäische Wirtschaftsgeschichte 10-19. Jahrhundert; Böhlau Verlag: Kölm, Germany, 2010.

63. Fressoz, J.-B. L'Apocalypse Joyeuse-Une Histoire du Risque Technologique; Le Seuil: Paris, France, 2012.

64. Palsson, G.; Szerszynski, B.; Sörlin, S.; Marks, J.; Avril, B.; Crumley, C.; Hackmann, H.; Holm, P.; Ingram, J.; Kirman, A.; et al. Reconceptualizing the "Anthropos" in the Anthropocene: Integrating the Social Sciences and Humanities in Global Environmental Change Research. Environ. Sci. Policy 2013, 28, 2-13. [CrossRef]

65. Kareiva, P.; Fuller, E. Beyond Resilience: How to Better Prepare for the Profound Disruption of the Anthropocene. Glob. Policy 2016, 7, 107-118. [CrossRef]

66. Allenby, B.R.; Sarewitz, D. The Techno-Human Condition; The MIT Press: Cambridge, MA, USA, 2011.

67. Nicholls, R. Planning for the impacts of sea level rise. Oceanography 2011, 24, 144-157. [CrossRef]

68. Kopp, R.E.; Horton, R.M.; Little, C.M.; Mitrovica, J.X.; Oppenheimer, M.; Rasmussen, D.J.; Strauss, B.H.; Tebaldi, C. Probabilistic 21st and 22nd century sea-level projections at a global network of tide-gauge sites. Earth's Future 2014, 2, 383-406. [CrossRef]

69. Godin-Beekmann, S. The stratospheric ozone layer and the Montreal Protocol. La Meteorologie 2013, 8, 59-66.

70. Wu, Y.; Polvani, L.M.; Seager, R. The importance of the Montreal Protocol in protecting Earth's hydroclimate. J. Clim. 2013, 26, 4049-4068. [CrossRef]

71. Jacobs, J.R. The precautionary principle as a provisional instrument in environmental policy: The Montreal Protocol case study. Environ. Sci. Policy 2014, 37, 161-171. [CrossRef]

72. Solomon, S.; Ivy, D.J.; Kinnison, D.; Mills, M.J.; Neely, R.R.; Schmidt, A. Emergence of healing in the Antarctic ozone layer. Science 2016, 353, 269-274. [CrossRef] [PubMed]

73. Asafu-Adjaye, J.; Blomqvist, L.; Brand, S.; Brook, B.; Defries, R.; Ellis, E.C.; Keith, D.; Foreman, C.; Lewis, M.; Lynas, M.; et al. An Ecomodernist Manifesto. 2015. Available online: http://www.ecomodernism.org/ manifesto (accessed on 10 January 2017).

74. Anshelm, J.; Hansson, A. Battling Promethean dreams and Trojan horses: Revealing the critical discourses of geoengineering. Energy Res. Soc. Sci. 2014, 2, 135-144. [CrossRef]

75. Bonneuil, C.; Fressoz, J.-B. L'événement Anthropocène-La Terre, L'histoire et Nous; Le Seuil: Paris, France, 2013. 
76. European Environmental Agency (EEA). Litter in Our Seas; EEA: Copenhagen, Denmark, 2014. Available online: http:/ / www.eea.europa.eu/signals/signals-2014/close-up/litter-in-our-seas (accessed on 10 January 2017).

77. Crona, B.; Wutich, A.; Brewis, A.; Gartin, M. Perceptions of climate change: Linking local and global perceptions through a cultural knowledge approach. Clim. Chang. 2013, 119, 519-531. [CrossRef]

78. Javeline, D.; Shufeldt, G. Scientific opinion in policymaking: the case of climate change adaptation. Policy Sci. 2014, 47, 121-139. [CrossRef]

79. Biermann, F.; Bai, X.; Bondre, N.; Broadgate, W.; Arthur Chen, C.-T.; Dube, O.P.; Erisman, J.W.; Glaser, M.; van der Hel, S.; Lemos, M.C.; et al. Down to Earth: Contextualizing the Anthropocene. Glob. Environ. Chang. 2016, 39, 341-350. [CrossRef]

80. Scolobig, A.; Thompson, M.; Linnerooth-Bayer, J. Compromise not consensus: Designing a participatory process for landslide risk mitigation. Nat. Hazards 2016, 81, 45-68. [CrossRef]

81. Ministry of Transport and Communications of Finland. Sulphur Content in Ships Bunker Fuel in 2015: A Study on the Impacts of the New IMO; Ministry of Transport and Communicatoins: Helsinki, Finland, 2009.

82. Jager, M. Sulphur Emission Regulation: Changing the Market for Bunker Fuels. Master's Thesis, Delft University of Technology, Delft, The Netherlands, 2012.

83. Isendahl, $\mathrm{C}$. The Anthropocene forces us to reconsider adaptationist models of human-environment interactions. Environ. Sci. Technol. 2010, 44, 6007. [CrossRef] [PubMed]

84. Hulme, M. Meet the humanities. Nat. Clim. Chang. 2011, 1, 177-179. [CrossRef]

85. Pievani, T. Geoethics and philosphy of Earth Sciences: The role of geophysical factors in human evolution. Ann. Geophys. 2012, 53. [CrossRef]

86. Lynam, T.; Brown, K. Mental models in human-environment interactions: Theory, policy implications, and methodological explorations. Ecol. Soc. 2012, 17, 3-5. [CrossRef]

87. Latour, B. Telling Friends from Foes in the Time of the Anthropocene. Thinking the Anthropocene, Paris, 14-15 November 2013. Available online: http:/ / www.bruno-latour.fr/sites/default/files/131-FRIENDSFOES.pdf (accessed on 10 Januray 2017).

88. Hamilton, C. Human destiny in the Anthropocene. In The Anthropocene and the Environmental Crisis; Hamilton, C., Bonneuil, C., Gemenne, F., Eds.; Routledge: Abingdon, UK, 2015; pp. 32-43.

89. Blühdorn, I. A much-needed renewal of environmentalism? Eco-politics in the Anthropocene. In The Anthropcene and the Environmental Crisis; Hamilton, C., Bonneuil, C., Gemenne, F., Eds.; Routledge: Abingdon, UK, 2015; pp. 157-167.

90. De Graaf, R.; van de Giesen, N.; van de Ven, F. Alternative water management options to reduce vulnerability for climate change in the Netherlands. Nat. Hazards 2009, 51, 407-422. [CrossRef]

91. Mees, H.L.P.; Driessen, P.P.J.; Runhaar, H.A.C. Legitimate adaptive flood risk governance beyond the dikes: The cases of Hamburg, Helsinki and Rotterdam. Reg. Environ. Chang. 2014, 14, 671-682. [CrossRef]

92. Weisz, H.; Clark, E. Society-nature coevolution: Interdisciplinary concept for sustainability. Geogr. Ann. Ser. B Hum. Geogr. 2011, 93, 281-287. [CrossRef]

93. Sayre, N.F. The Politics of the Anthropogenic. Annu. Rev. Anthropol. 2012, 41, 57-70. [CrossRef]

94. Bonatti, E. The Anthropocene: Of time, mice, and men. Rendiconti Lincei 2014, 25, 21-27. [CrossRef]

95. Chakrabarty, D. The Anthropocene and the convergence of histories. In The Anthropcene and the Environmental Crisis; Hamilton, C., Bonneuil, C., Gemenne, F., Eds.; Routledge: Abingdon, UK, 2015; pp. 32-43.

96. Hamilton, C. The Theodicy of the "Good Anthropocene". Environ. Humanit. 2015, 7, 233-238. [CrossRef]

97. Chew, S.; Sarabia, D. Nature-culture relations: Early globalization, climate changes, and system crisis. Sustainability 2016, 8, 78. [CrossRef]

98. Kvellestad Isaksen, K. Where Does Nature End and Culture Begin? Available online: http:/ /cas.oslo.no/fullwidth-article/where-does-nature-end-and-culture-begin-article1830-1082.html (accessed on 10 January 2017).

99. Emanuel, R.E.; Buckley, J.J.; Caldwell, P.V.; McNulty, S.G.; Sun, G. Influence of basin characteristics on the effectiveness and downstream reach of interbasin water transfers: Displacing a problem. Environ. Res. Lett. 2015, 10, 124005. [CrossRef]

100. Dietz, S.; Groon, B.; Pizer, W.A. Weighing the cost and benefits of climate change to our children. Future Child. 2016, 26, 133-155. [CrossRef]

101. Abd-El Monsef, H.; Smith, S.E.; Darwish, K. Impacts of the Aswan High Dam after 50 Years. Water Resour. Manag. 2015, 29, 1873-1885. [CrossRef] 
102. Sutcliffe, J.; Hurst, S.; Awadallah, A.G.; Brown, E.; Hamed, K. Harold Edwin Hurst: The Nile and Egypt, past and future. Hydrol. Sci. J. 2016, 61, 1557-1570. [CrossRef]

103. Hake, J.-F.; Fischer, W.; Venghaus, S.; Weckenbrock, C. The German Energiewende-History and status quo. Energy 2015, 92, 532-546. [CrossRef]

104. Von Storch, H.; Emeis, K.; Meinke, I.; Kannen, A.; Matthias, V.; Ratter, B.M.W.; Stanev, E.; Weisse, R.; Wirtz, K. Making coastal research useful-Cases from practice. Oceanologia 2015, 57, 3-16. [CrossRef]

105. Weber, J. Container Shipping in the European Ranges and the Potential Viability of the Newcomer Jade-Weser Port. Ocean Yearbook Online 2005, 19, 336-356. [CrossRef]

106. Newman, P.; McKenzie, R. UV impacts avoided by the Montreal Protocol. Photochem. Photobiol. Sci. 2011, 10, 1152-1160. [CrossRef] [PubMed]

107. Cancer Council Australia Risks and Benefits of Sun Exposure Summary Statement. 2007. Available online: http://wiki.cancer.org.au/policy/Position_statement_-_Risks_and_benefits_of_sun_exposure (accessed on 10 Januray 2017).

108. Brown, A. Just Enough: Lessons in Living Green from Traditional JAPAN; Tuttle Publishing: Tokyo, Japan, 2012.

109. Harris, P. Routledge Handbook of Global Environmental Politics; Routledge: Abingdon, UK, 2013.

110. Hallegatte, S.; Mach, K.J. Make climate-change assessments more relevant. Nature 2016, 534, $613-615$. [CrossRef] [PubMed]

111. Hansen, J.; Sato, M.; Hearty, P.; Ruedy, R.; Kelley, M.; Masson-Delmotte, V.; Russell, G.; Tselioudis, G.; Cao, J.; Rignot, E.; et al. Ice melt, sea level rise and superstorms: Evidence from paleoclimate data, climate modeling, and modern observations that $2{ }^{\circ} \mathrm{C}$ global warming is highly dangerous. Atmos. Chem. Phys. Discuss. 2015, 15, 20059-20179. [CrossRef]

112. Pearce, F. The big green divide. New Sci. 2015, 226, 26-27. [CrossRef]

113. Librová, H.; Pelikán, V. Ethical Motivations and the Phenomenon of Disappointment in Two Types of Environmental Movements: Neo-Environmentalism and the Dark Mountain Project. Environ. Values 2016, 25, 167-193. [CrossRef]

114. Fox, T.; Chapman, L. Engineering geo-engineering. Meteorol. Appl. 2011, 18, 1-8. [CrossRef]

115. Bracmort, K.; Lattanzio, R.K. Geoengineering: Governance and Technological Policy; Congressional Research Service: Washington, DC, USA, 2013; p. 42.

116. Barrett, S. The Incredible Economics of Geoengineering. Environ. Resour. Econ. 2008, 39, 45-54. [CrossRef]

117. Banerjee, B. The limitations of geoengineering governance in a world of uncertainty. Stanf. J. Law Sci. Policy 2011, 240, 15-36.

118. Bodansky, D. The who, what, and wherefore of geoengineering governance. Clim. Chang. 2013, 121, 539-551. [CrossRef]

119. Hamilton, C. No, we should not just "at least do the research". Nature 2013, 496, 139. [CrossRef] [PubMed]

120. Rayner, S.; Heyward, C.; Kruger, T.; Pidgeon, N.; Redgwell, C.; Savulescu, J. The Oxford Principles. Clim. Chang. 2013, 121, 499-512. [CrossRef]

121. Ellis, E.C.; Richerson, P.J.; Mesoudi, A.; Svenning, J.-C.; Odling-Smee, J.; Burnside, W.R. Evolving the human niche. Proc. Natl. Acad. Sci. USA 2016, 113, E4436. [CrossRef] [PubMed]

122. Tattersal, I. Masters of the Planet: The Search for Our Human Origins; Palgrave Macmillan: New York, NY, USA, 2012.

123. Viollet, P.-L. L'hydraulique dans les Civilisations Anciennes: 5000ans D'histoire; Presses des Ponts et Chausssées: Paris, France, 2000.

124. Millet, B.; Tronchère, H.; Goiran, J.-P. Hydrodynamic modeling of the Roman Harbor of Portus in the Tiber Delta: The impact of the North-Eastern Channel on current and sediment dynamics. Geoarchaeology 2014, 29, 357-370. [CrossRef]

125. Mensing, S.; Tunno, I.; Cifani, G.; Passigli, S.; Noble, P.; Archer, C.; Piovesan, G. Human and climatically induced environmental change in the Mediterranean during the Medieval Climate Anomaly and Little Ice Age: A case from central Italy. Anthropocene 2016, 15, 49-59. [CrossRef]

126. Ellis, E.C.; Kaplan, J.O.; Fuller, D.Q.; Vavrus, S.; Klein Goldewijk, K.; Verburg, P.H. Used planet: A global history. Proc. Natl. Acad. Sci. USA 2013, 110, 7978-7985. [CrossRef] [PubMed]

127. Heede, R. Tracing anthropogenic carbon dioxide and methane emissions to fossil fuel and cement producers, 1854-2010. Clim. Chang. 2014, 122, 229-241. [CrossRef] 
128. Zalasiewicz, J.; Williams, M.; Waters, C.N.; Barnosky, A.D.; Palmesino, J.; Ronnskog, A.-S.; Edgeworth, M.; Neal, C.; Cearreta, A.; Ellis, E.C.; et al. Scale and diversity of the physical technosphere: A geological perspective. Anthropocene Rev. 2016. [CrossRef]

129. Tickell, C. Societal responses to the Anthropocene. Philos. Trans. Ser. A Math. Phys. Eng. Sci. 2011, 369, 926-932. [CrossRef] [PubMed]

130. Bai, X.; van der Leeuw, S.; O’Brien, K.; Berkhout, F.; Biermann, F.; Brondizio, E.S.; Cudennec, C.; Dearing, J.; Duraiappah, A.; Glaser, M.; et al. Plausible and desirable futures in the Anthropocene: A new research agenda. Glob. Environ. Chang. 2015, 39, 351-362. [CrossRef]

131. Chopra, A.; Lineweaver, C.H. The case for a Gaian Bottleneck: The biology of habitability. Astrobiology 2016, 16, 7-22. [CrossRef] [PubMed]

132. Denevan, W.M. The Pristine Myth: The landscape of the Americas in 1492. Ann. Assoc. Am. Geogr. 1992, 82, 369-385. [CrossRef]

133. Denevan, W.M. The Pristine Myth: Revisited. Geogr. Rev. 2011, 101, 576-591. [CrossRef]

134. Rickards, L.A. Metaphor and the Anthropocene: Presenting Humans as a Geological Force. Geogr. Res. 2015, 53, 280-287. [CrossRef]

135. Macnaghten, P.; Szersynski, B. Living the global social experiment: An analysis of public discourse on solar radiation management and its implications for governance. Glob. Environ. Chang. 2013, 23, 465-474. [CrossRef]

136. Mengel, M.; Levermann, A.; Frieler, K.; Robinson, A.; Marzeion, B.; Winkelmann, R. Future sea level rise constrained by observations and long-term commitment. Proc. Natl. Acad. Sci. USA 2016, 113, 2597-2602. [CrossRef] [PubMed]

137. Williamson, P. Emissions reduction: Scrutinize $\mathrm{CO}_{2}$ removal methods. Nature 2016, 530, 153-155. [CrossRef] [PubMed]

138. Biermann, F. "Earth system governance" as a crosscutting theme of global change research. Glob. Environ. Chang. 2007, 17, 326-337. [CrossRef]

139. Loevbrand, E.; Beck, S.; Chilvers, J.; Forsyth, T.; Hedrén, J.; Hulme, M.; Lidskog, R.; Vasileiadou, E. Who speaks for the future of Earth? How critical social science can extend the conversation on the Anthropocene. Glob. Environ. Chang. 2015, 32, 211-218. [CrossRef]

140. Jennings, B. WHO(SE) ARE WE. Minding Nat. 2016, 93, 4-10.

141. Cairney, P. The Politics of Evidence-Based Policy Making; Palgrave Macmillan: London, UK, 2016.

142. Barnosky, A.D.; Ehrlich, P.R.; Hadly, E.A. Avoiding collapse: Grand challenges for science and society to solve by 2050. Elementa Sci. Anthropocene 2016, 4, 94. [CrossRef] 